While the choice to use illustrations in Portraits of Violence is supported by the authors' educational mission, the use of visuals is not equally effective in all chapters. In the most successful ones, the images make concepts and ideas easier to grasp, or offer a layer of added subtlety and nuance that the text alone cannot. However, in other chapters the illustrations add little to the effective and concise introduction provided in the text, and seem gimmicky and superfluous. Overall, the book provides a good introduction to the ten thinkers and lays out thought provoking questions about violence, in a visual manner that is clearly geared towards a North American reader. This book has the potential to draw in readers to engage with challenging theory.

Noa Nahmias

York University

\title{
Nina Caputo and Liz Clarke, Debating Trutb: The Barcelona Disputation of 1263: A Graphic History (New York: Oxford University Press, 2017). 256pp. Paperback \$24.95.
}

The graphic history promised in the title occupies the first quarter of this volume (84 pages) and is devoted to a portrait of the 1263 Barcelona disputation. The remaining sections of the book provide traditional and useful historical considerations, including translations of the key sources for the Barcelona disputation (Part II, 46 pages), observations on the context of the disputation (Part III, 42 pages), depiction of the historiography of the encounter (Part IV, 34 pages), and directions for further study of the event (Part V, 11 pages). The first half of the historiography section identifies diverse perspectives on the Barcelona event, which has aroused considerable scholarly discord; the second half explains Nina Caputo's decision to present the Barcelona engagement in graphic format.

Prior to engaging directly with the graphic history, let me address key background issues that frame it. What was the precise nature of the engagement that took place in Barcelona in 1263? The title already provides two descriptorsdisputation and debate — and both are problematic. In her preface, Caputo notes the ubiquity of literary depictions of Christian-Jewish religious argumentation and suggests that "there is good reason to believe that Jews and Christians discussed and debated theological differences on an individual basis" (xiv). She further indicates that there were occasional "public disputations in which kings played an instrumental role and leaders from the Jewish community were obliged to defend Jewish texts and practices" (xiv). Caputo highlights four such instances: 1240 in Paris; 1263 in Barcelona; 1271 in Paris; and 1413-14 in Tortosa.

This listing points to the loose and potentially confusing meanings of the term "disputation." The Paris "disputation"—it has been widely agreed—was 
in fact a trial of the Talmud, which resulted, as Caputo notes, in a massive burning of Talmud manuscripts in Paris in 1242; it further led to widespread censorship of the Talmud and other Jewish texts across Europe and over many centuries. The other three royally-sponsored engagements were quite different from the Paris trial of the Talmud. Identifying them as "disputations" should not be taken to mean that they were theoretically-oriented and balanced intellectual encounters between Christian and Jewish scholars. Rather, all three were royallysponsored missionizing efforts in which Jews were confronted with innovative Christian arguments grounded heavily in post-biblical Jewish sources. Caputo points clearly to this reality in her preface: "For Nahmanides' part, a successful defense of Judaism and of a Jewish interpretation of the Talmud at any cost was paramount. His position in the disputation was defensive" (xii).

Both terms utilized in the title of this volume, "disputation" and "debate," are likely to mislead, since both terms usually reflect an element of equality between conflicting protagonists. In fact, the Barcelona "disputation" involved no such equality. In Barcelona, the Christian side was in the dominant and controlling position - the truth of Christianity was by no means to come under consideration. The entire proceeding was intended to convince Christian and Jewish observers that authoritative post-biblical Jewish sources had acknowledged Christian truth and that thirteenth-century Jews had no real choice but to follow these authoritative sources and accept the Christian truth that they had embraced (1011). The Barcelona "disputation" did not involve "debating truth," since "debating truth" means that one side or the other might emerge victorious. The Barcelona "disputation" could not have resulted in Jewish victory or Christian defeat.

In the second section of Part IV of the volume, devoted to the complex historiographic positions that have emerged on the Barcelona engagement, $\mathrm{Ca}$ puto discusses her decision to tell the story in graphic form:

A chance encounter with the relatively new genre of 'graphic history' suggested it as an approach that might provide an opportunity to engage in a different sort of discussion with and about the key sources. It was my intention to use graphic signs to draw readers' attention to the historiographic issues that made — and continue to make - the Barcelona disputation interesting to me (199).

This sounds very promising. However, subsequently, Caputo indicates that she "knew from the very outset that I wanted to tell Nahmanides' version of the disputation" (209). This is in fact precisely what she and Liz Clarke do. The graphic version of the Barcelona disputation begins with Nahmanides arriving at the port of Acre in the Latin Kingdom of Jerusalem in 1267 and reflecting back on his Barcelona experience and its aftermath. This way of telling the tale is intriguing 
and attractive, but it hardly engages the complicated issues of the reliability of the Nahmanides perspective on the events of 1263. Rather, the Nahmanides perspective is very much privileged. Thus, for example, the lengthy speech that Nahmanides portrays himself as giving at the beginning of the second day of the proceedings, and which includes criticisms of Christianity that are hard to imagine being uttered in this public setting, is simply included in the graphic depiction without comment (29).

I have emerged from this encounter with graphic history unconvinced that this new technique of presenting history advances the cause of sophistication. On the other hand, it has alternative virtues. Like graphic novels, graphic history has the capacity to evoke deep interest and involvement on the part of the reader/viewer. The Caputo/Clarke presentation of the 1263 events at Barcelona has the potential to arouse student attention and to set the stage for rich classroom activity. Indeed, Part V seems to be oriented toward teachers and students who might be using the volume. Graphic history is clearly in its infancy, and much evolution will surely take place. Graphic history may well turn out to be of valuable classroom use, attracting students to immerse themselves in important historical events, and utilizing their heightened interest to urge and guide them toward deeper understanding of these events. The present early effort seems to me to have this potential, and I very much hope that educators will explore this utilization.

Robert Chazan

New York University

\section{Kim Scipes, ed., Building Global Labor Solidarity in a Time of Accelerat- ing Globalization (Chicago: Haymarket Books, 2016). 296pp. Paperback $\$ 19.00$.}

The industrial and political force of the labour movement throughout much of the world has been decimated by the twin forces of globalization and neoliberalism. How this could be turned around is attracting much critical reflection, and Kim Scipes's edited collection Building Global Labor Solidarity in a Time of Accelerating Globalization is a product of this. It brings together some of the contributions to a forum organized by the journal Working USA that were not published in the 2014 special issue of the journal. The collection seeks to highlight strategic initiatives, such as "rank and file" moves to forge cross-border solidarity links or the emergence of social movement unionism connecting with new social movements fighting racism and sexism, to contribute to meeting the challenge of overcoming the labour movement's malaise. 